\title{
RESIKO BAYI BERAT LAHIR RENDAH TERHADAP PENURUNAN KADAR BILIRUBIN
}

\author{
Poppy Fransisca Amelia ${ }^{1}$, Isy Royhanaty ${ }^{2}$, Diah Oktaviana ${ }^{3}$ \\ ${ }^{1,2,3}$ Prodi Kebidanan, STIKes Karya Husada Semarang \\ E-mail:poppymarlaen@gmail.com
}

\begin{abstract}
ABSTRAK
Berat bayi adalah salah satu faktor yang dapat mempengaruhi Kadar Bilirubin menjadi tinggi. Pada Bayi Berat Lahir Rendah (BBLR). Kadar Bilirubin tinggi disebabkan oleh kematangan organ yang belum maksimal, berkurang nya jumlah enzim yang diambil dan kenaikan bilirubin serum yang cenderung sama atau sedikit lebih lambat tetapi jangka waktunya lebih lama dari biasanya sehingga mengakibatkan Kadar Bilirubin meningkat.Tujuan penelitian ini adalah untuk mengetahui korelasi antara Berat Bayi Lahir dengan Kadar Bilirubin pada BBLR.Jenis Penelitian yang digunakan adalah penelitian kuantitatif dengan pendekatan cross sectional dan studi retrospektif. Waktu Penelitian bulan Desember sampai bulan Juni 2018. Sampel Penelitian berjumlah 148 bayi, dan menggunakan data sekunder. Analisa menggunakan korelasi rank spearman. Hasil Penelitian didapatkan p-value 0,000 dengan korelasi rank spearman -0,601 yang artinya korelasi negatif yang menunjukkan kekuatan dalam kategori tinggi yaitu semakin rendah berat badannya maka semakin tinggi kadar bilirubinnya. Ada korelasi yang signifikan antara berat bayi lahir dengan kadar bilirubin.
\end{abstract}

Kata Kunci : Bayi Berat Lahir Rendah; Berat lahir; Kkadar Bilirubin.

\section{THE RISK OF NEW BORN BABY WEIGHT TOWARD THE DECREASE OF BILIRUBIN IN LOW BIRTH WEIGHT BABIES.}

\begin{abstract}
Baby's weight is one of the factors that can affect the level of Bilirubin to be high. In Low Birth Weight Babies (LBW). High levels of bilirubin are caused by organ maturity that has not been maximal, decreases the amount of enzymes taken and increases in serum bilirubin which tends to be the same or slightly slower but longer than usual, resulting in increased bilirubin levels. The purpose of this study was to determine the correlation between weight Babies born with bilirubin levels in LBW. Type of research used was quantitative research with cross sectional approach and retrospective study. Research had conducted from December to June 2018. The research sample consisted of 148 infants, and used secondary data. The analysis used Spearman rank correlation. The results obtained $\mathrm{p}$-value 0,000 with spearman rank correlation $-0,601$ which means a negative correlation that shows strength in the high category, namely the lower the weight, the higher the bilirubin level. There is a significant correlation between the weight of the baby born with the bilirubin level.weight.
\end{abstract}

Keyword : Birth Weight; Bilirubin Value; Low Birth Weight

Jurnal SMART Kebidanan Sekolah Tinggi Ilmu Kesehatan (STIKes) Karya Husada Semarang

www.stikesyahoedsmg.ac.id/ojs/index.php/sjkb 


\section{Pendahuluan}

Bayi Berat Lahir Rendah (BBLR) adalah bayi baru lahir yang berat badannya saat lahir kurang dari 2500 gram.BBLR tidak hanya dapat terjadi pada bayi prematur, tetapi juga pada bayi cukup bulan. Morbiditas dan mortalitas dalam berat lahir bayi beresiko tinggi pada kelompok BBLR sehingga membutuhkan perawatan yang intensif. Berat lahir merupakan indikator penting perkiraan maturitas dan kemampuan neonatus untuk bisa bertahan. Sedangkan kematian bayi luar kandungan atau kematian post neonatal disebabkan oleh faktorfaktor yang berkaitan dengan pengaruh dari luar. Salah satu penyebab kematian bayi luar kandungan adalah hiperbilirubin, dimana hiperbilirubin merupakan salah satu fenomena klinis yang paling sering ditemukan pada bayi baru lahir dalam minggu pertama dalam kehidupannya. Insiden hiperbilirubinemia di Indonesia 51,47 \%.Hiperbilirubin terbagi atas dua, fisiologis dan patologis dimana hiperbilirubin fisiologis adalah keadaan hiperbilirubin karena faktor fisiologis yang merupakan gejala normal dan sering dialami bayi baru lahir. Hiperbilirubin patologis adalah suatu keadaan dimana kadar konsentrasi bilirubin dalam darah mencapai nilai yang melebihi batas normal hiperbilirubin dan mempunyai potensi untuk menimbulkan kern ikterik.

Risiko terjadinya ikterus pada bayi baru lahir meningkat $80 \%$ pada bayi prematur atau bayi dengan berat lahir rendah jika dibandingkan dengan bayi yang cukup bulan. Peningkatan risiko tersebut terjadi akibat kondisi organ yang belum matur terutama organ hepar karena akan mengganggu jalannya metabolisme bilirubin. Dampak yang terjadi pada jangka pendek, bayi akan mengalami kejang-kejang, sementara dalam jangka panjang bayi bisa mengalami cacat neurologis contohnya ketulian, gangguan bicara dan retardasi mental. Jadi, penting sekali mewaspadai keadaan umum si bayi dan harus terus dimonitor secara ketat.

\section{TinjauanTeoritis}

\section{Bayi Berat Badan Lahir Rendah (BBLR)}

Bayi Berat Lahir Rendah (BBLR) adalah berat bayi saat lahir kurang dari 2500 gram yang merupakan hasil dari kelahiran prematur (sebelum usia 37 minggu kehamilan). Bayi dengan berat badan lahir rendah sangat erat kaitannya dengan mortalitas dan morbiditas, sehingga akan menghambat pertumbuhan dan perkembangan kognitif serta penyakit kronis di kemudian hari. Bayi berat badan lahir rendah (BBLR) merupakan bayi yang lahir dengan berat badan kurang dari 2500 gram saat lahir. Bayi BBLR sebagian besar dikarenakan 
retardasi pertumbuhan intrauterin (IUGR) dengan usia kehamilan kurang dari 37 minggu. Bayi BBLR memiliki risiko empat kali lebih tinggi dari kematian neonatal daripada bayi yang berat badan lahir 2500-3499 gram.Secara umum bayi BBLR ini berhubungan dengan usia kehamilan yang belum cukup bulan (prematur) disamping itu juga disebabkan dismaturitas. Artinya bayi lahir cukup bulan (usia kehamilan 38 minggu) tapi berat badan (BB) lahirnya lebih kecil dari masa kehamilannya, yaitu tidak mencapai 2500 gram. Masalah ini terjadi karena adanya gangguan pertumbuhan bayi sewaktu dalam kandungan yang disebabkan oleh penyakit ibu seperti adanya kelainan plasenta, infeksi, hipertensi, dan keadaan - keadaan lain yang menyebabkan suplai makanan ke bayi jadi berkurang.

\section{Kadar Bilirubin}

Bilirubin adalah produk utama dari penguraian sel darah merah yang tua. Bilirubin disaring dari darah oleh hati dan dikeluarkan pada cairan empedu. Sebagaimana hati menjadi semakin rusak, bilirubin total akan meningkat. Bilirubin mengandung bahan pewarna, yang memberi warna pada kotoran, bila tingkatnya sangat tinggi, kulit dan mata dapat menjadi kuning, yang mengakibatkan gejala ikterus. Bilirubin merupakan produk pemecahan sel darah merah. Pemecahan pertama dari sistem RES (Retikuloendotelial system) yang diawali dengan pelepasan besi dan rantai peptida globulin. Bilirubin berawal dari turunan cicin porfirin yang terbuka dan menjadi rantai lurus, dalam sistem RES, turunan tersebut dikenal sebagai biliverdin yang kemudian dikeluarkan ke sirkulasi, di dalam plasma, bilirubin diikat oleh albumin yang dikenal sebagai bilirubin indirek. Metabolisme bilirubin diawali dengan reaksi proses pemecahan heme oleh enzim hemoksigenase yang mengubah biliverdin menjadi bilirubin oleh enzim bilirubin reduksitase. Bilirubin dibagi menjadi 2 jenis yaitu bilirubin indirek merupakan bilirubin yang belum mengalami konjugasi oleh hati dengan asam glukoronat sedangkan bilirubin direk yang telah mengalami konjugasi dengan asam glukoronat di dalam hati. Pemeriksaan bilirubin di laboratorium untuk membedakan bilirubin direk dan indirek, maka dilakukan juga pemeriksaan bilirubin total yang merupakan jumlah bilirubin direk dan indirek

\section{MetodePenelitian}

Jenis penelitian yang digunakan adalah penelitian kuantitatifdengan pendekatan cross sectional dan studi retrospektif. Sampel dalam penelitian ini adalah semua bayi Berat Badan Lahir Rendah yang dirawat di RSUD Sunan Kalijaga Demak dari Januari sampai Desember 
2017 yang berjumlah 148 orang dengan menggunakan teknik total sampling. Variabel independen adalah Berat Bayi Lahir. Variabel dependen adalah Kadar Bilirubin. Instrumen yang digunakan adalah catatan medis yang digunakan untuk memperoleh data yang diperlukan dan cheklist BBLR yang pernahdirawat di ruang Bougenville RSUD Sunan Kalijaga Demak.Pada penelitian ini menggunakan uji normalitas untuk mengetahui apakah populasi data berdistribusi normal atau tidak. Karena data yang digunakan $>50$, maka uji normalitas yang digunakan adalah uji Kolmogorov Smirnov.Pada uji Kolmogorov Smirnov didapatkan hasil $\mathrm{p}=0,000$ atau $\mathrm{p}<0,05$ untuk variabel berat bayi dan kadar bilirubin yang menunjukkan data berdistribusi tidak normal, maka menggunakan rank spearman.

\section{Hasil Penelitian}

Korelasi berat lahir terhadap penurunan kadar bilirubin pada bayi bayi baru lahir secara bivariat dapat dilihat dalam tabel 1 berikut ini

Tabel 1 Gambaran Berat Bayi Lahir dan Kadar Bilirubin

\begin{tabular}{|c|c|c|c|c|c|c|c|}
\hline Kategori & Mean & Median & Min & Max & SD & $\begin{array}{l}\text { Kolmogorof- } \\
\text { smirnov }\end{array}$ & $\begin{array}{c}\mathbf{P} \\
\text { value }\end{array}$ \\
\hline $\begin{array}{l}\text { Berat } \\
\text { Lahir }\end{array}$ & 2047,03 & 2100 & 1450 & 2450 & 304,362 & 0,000 & \multirow{2}{*}{0,000} \\
\hline $\begin{array}{l}\text { Kadar } \\
\text { Billirubin }\end{array}$ & 11,28 & 11,00 & 3 & 20 & 3,064 & 0,000 & \\
\hline
\end{tabular}

Hasil Penelitian pada variabel berat bayi lahir menunjukkan nilai mean (nilai rata-rata pada keseluruhan responden) adalah 2.047 gram, nilai median atau nilai tengah adalah 2.100 gram, standar deviasi 304.362, nilai minimum atau nilai terendah berat bayi lahir sebesar 1.450 gram, dan nilai maksimum atau berat badan bayi baru lahir tertinggi adalah 2. 450 gram.

Hasil Penelitian pada variabel kadar bilirubin menunjukkan nilai mean atau nilai ratarata bilirubin pada penelitian ini adalah $11.28 \mathrm{mg} / \mathrm{dl}$, nilai median atau disebut juga nilai tengah sebesar $11.00 \mathrm{mg} / \mathrm{dl}$, standar deviasi 3.064, nilai minimum atau nilai kadar bilirubin terendah adalah $3 \mathrm{mg} / \mathrm{dl}$ dan nilai maksimum atau nilai tertinggi kadar bilirubin adalah 20 $\mathrm{mg} / \mathrm{dl}$.

Uji normalitas data dilakukan sebelum dianalisa dan hasil normalitas data dengan kolmogorov-Smirnov oleh karena jumlah sampel penelitian lebih dari 50 responden dengan 
taraf signifikan 0,05 , didapatkan hasil nilai $p=0.000$ atau $p<0.05$ untuk variabel berat bayi lahir yang berarti data berdistribusi tidak normal, dan uji normalitas untuk variabel Bilirubin didapatkan nilai $p=0.000$ atau $p<0.05$ yang berarti bahwa data juga berdistribusi tidak normal, maka uji Statistik yang paling sesuai adalah dengan uji korelasi spearman ( spearman rank).

Hasil uji korelasi spearman di dapatkan hasil $\mathrm{p}$ value 0.000 atau $\mathrm{p}<0.05$ yang artinya Ha diterima yaitu ada hubungan yang signifikan antara berat bayi lahir dengan kadar bilirubin pada bayi BBLR di ruang Bougenville RSUD Sunan Kalijaga Kabupaten Demak. Sedangkan kekuatan hubungan di tunjukkan dengan $r$ correlation coefficient=-,601 yang artinya kekuatan dalam kategori tinggi, sedangkan nilai korelasi yang hasilnya negatif menunjukkan hubungan yang berlawanan, sehingga dapat disimpulkan bahwa semakin rendah berat badan lahir bayi akan semakin tinggi kadar bilirubinnya dan sebaliknya.

\section{Pembahasan}

Hasil penelitian menunjukkan ada hubungan yang signifikan antara berat bayi lahir dengan kadar bilirubin pada bayi BBLR di ruang Bougenville RSUD Sunan Kalijaga Kabupaten Demak. Hal ini terjadi karena BBLR lebih mudah mengalami peningkatan kadar bilirubin dibandingkan dengan bayi yang memiliki berat badan lahir normal. BBLR dapat menyebabkan berkurangnya jumlah enzim yang diambil dan menyebabkan pengurangan reduksi bilirubin oleh sel hepar. Selain itu pada BBLR kenaikan bilirubin serum cenderung sama atau sedikit lebih lambat daripada kenaikan bilirubin pada bayi yang berat badannya normal tetapi jangka waktunya lebih lama dari biasanya sehingga mengakibatkan kadar bilirubin lebih tinggi. Hal ini dikarenakan kematangan pada organ bayi dengan BBLR belum maksimal dibandingkan dengan bayi yang memiliki berat badan lahir normal. Proses pengeluaran bilirubin melalui organ hepar yang belum matang menyebabkan peningkatan kadar bilirubin pada bayi.Faktor yang mempengaruhi kadar bilirubin diantaranya ada faktor dari dalam dan dari luar. Faktor dari luar yang dapat mempengaruhi kadar bilirubin adalah sinar, suhu, waktu dan tabung penyimpanan. Sedangkan faktor dari dalam meliputi faktor maternal, faktor persalinan dan faktor neonatus. Pada faktor neonatus salah satu faktornya adalah karena berat bayi lahir. ${ }^{39}$ Bilirubin adalah produk utama dari penguraian sel darah merah yang tua. Peningkatan kadar bilirubin terjadi pada bayi baru lahir. Hal ini sesuai penelitian yang dilakukan oleh Yaestin (2017) tentang hubungan berat badan lahir rendah dengan kejadian ikterus di RS PKU Muhammadiyah Yogyakarta yang menyebutkan bahwa 
sebagian responden dengan BBLR sebesar $68.9 \%$ dan kejadian BBLSR adalah sebesar 31.1\% , dan hasil uji statistik $p$ value 0.025 atau $p<0.05$ yang artinya adanya hubungan yang signifikan antara berat badan lahir rendah dengan kejadian ikterus. Penelitian lain yang sesuai dilakukan oleh Hafidzah (2013) tentang faktor-faktor yang berhubungan dengan kejadian hiperbilirubinemia di ruang NICU RSUD Dr. Zainal Abidin Banda Aceh menyatakan bahwa BBLR merupakan salah satu faktor terjadinya hiperbilirubin dengan nilai uji statistik $p$ value 0.011 .

\section{Kesimpulan}

Ada korelasi negatif yang signifikan antara berat bayi lahir dengan kadar bilirubin di RSUD Sunan Kalijaga Demak dengan $p$ value $-0,601$.

\section{Saran}

Diharapkan ibu hamil dapat meningkatkan status gizi dengan mengonsumsi makanan bergizi sehingga dapat mengurangi jumlah kelahiran bayi dengan BBLR dan memiliki pengetahuan tentang bilirubin sehingga bila bayinya mengalami hiperbilirubin, dapat ditangani secara cepat sehingga tidak terjadi komplikasi akibat hiperbilirubin. Bidan dharapkan agar dapat meningkatkan pelayanan khususnya pada bayi BBLR dan hiperbilirubin dengan cara inisiasi menyusui dini, mengajarkan ibu metode kanguru dan dapat memberikan penatalaksanaan pada bayi dengan hiperbilirubin secara komprehensif.Penelitian ini diharapkan dapat dijadikan data dasar dan masukan untuk melakukan penelitian lainnya yang berkaitan dengan berat bayi lahir dan hiperbilirubin dalam upaya menurunkan angka kematian pada bayi.

\section{DaftarPustaka}

Al Khadar A. (2010). Korelasi Nilai APGAR menit kelima dengan kadar transaminase seru pada BBL. Jurnal Sari Pediatri.

Anggraeni, Yetty. (2013). Hubungan antara Persalinan Prematur Dengan Hiperbilirubin pada neonatus, Tanjungkarang.

AY. Sutedjo. (2009). Buku Saku, Mengenal Penyakit Melalui Hasil Pemeriksaan Laboratorium, Amara Books, Yogyakarta. 
Behrman, Richard et al. (2004). Immunophenotyping in leukimia and its diagnostic signifience. Medical Journal of Indonesia. Volume 13. Number 3 : July-September 2004.

Data Register Ruang Bougenville RSUD Sunan Kalijaga Demak.

Dewi, V.L.N. (2014). Asuhan Neonatus Bayi dan Anak Balita. Jakarta : EGC

Dinas Kesehatan Kabupaten Demak. (2012). Profil Dinas Kesehatan Kabupaten Demak. [Diakses dari http://dinkes.demakkab.go.id].

Dinas Kesehatan Provinsi Jawa Tengah (2009). Profil Kesehatan Provinsi Jawa Tengah. http://www.dinkesjatengprov.go.id/dokumen/profil/2009/profil2009br.pdf (diakses 30 Mei 2013).

Donna L. Wong, et all . (2008). Buku Ajar Keperawatan Pediatrik. Cetakan pertama Jakarta : EGC.

Hafizah \& imelda. (2013). Faktor-faktor yang berhubungan dengan kejadian Hiperbilirubinemia di Ruang NICU RSUD Zainal Abidin Banda Aceh.

Hardjono. (2003. Interpretasi Hasil Tes Laboratorium Diagnostik. Makasar. Lembaga Penerbitan Universitas Hasanudin.

Hidayat, A.A. (2002). Pengantar Dokumentasi Proses Keperawatan. Jakarta : EGC).

Hidayat. 2007. Metodologi Penelitian Kesehatan. Jakarta : Rineka Cipta.

Jitowiyono, S dan Weni Kristiyanasari. (2010). Asuhan Keperawatan Neonatus dan Anak. Jakarta. Nuha medika. Cetakan I.

Joyce, Marsha Weil, Emili Calhourn. (2011). Models of Teaching, Edisi 8. Yogyakarta:Pustaka Pelajar.

Kementrian Kesehatan Republik Indonesia. (2013). Riset Kesehatan Dasar. Jakarta : Badan Penelitian dan Pengembangan Kesehatan.

Manuaba. (2012). Pengantar kuliah obstetri. Jakarta : EGC

Nelson.(2010).Ilmu Kesehatan Anak Vol.2. Jakarta : EGC.

Nike.(2014). Manajemen Masalah Bayi Baru Lahir. Jakarta : EGC.

Notoadmojo.2012. Metodologi Penelitian Kesehatan, Edisi 2, Jakarta : Rina Cipta.

Nursalam.(2013). Konsep Penerapan Metode Penelitian Ilmu Keperawatan. Jakarta : Salemba Medika.

Proverawati. (2010). Buku Asuhan Neonatus Berat Badan Lahir Rendah (BBLR). Yogyakarta : Nuha Medika.

Putri, R.A dan Mexitalia, M. (2014). Faktor Resiko Hiperbilirubin pada neonatus. Medika hospitalia Med Hosp 2014 ; Vol 2 (2) :105-109. 
Saputra, Reza Gusni. (2016). Perbedaan Kejadian Ikterus Neonatorum antara Bayi Prematur dan Bayi Cukup Bulan pada Bayi dengan Berat Lahir Rendah di RS PKU Muhammadiyah Surakarta.

Saryono \&Ari Setiawan. (2011). Metode Penelitian Kebidanan DIII, DIV, SI, S2. Yogyakarta : Nuha Medika

Sugiyono. (2010). Metode Penelitian Pendidikan Pendekatan Kuantitatif, Kualitatif dan R\&D. Bandung : Alfabeta.

Wijayaningsih, K.S.(2013). Asuhan Keperawatan Anak. Jakarta : Trans Info Media.

Yaestin. (2017). Hubungan Berat Badan Lahir Rendah dengan kejadian Ikterus di PKU Muhammadiyah Yogyakarta. 